\title{
Corporate social entrepreneurship versus social intrapreneurship: same idea, different trajectories?
}

\author{
Shahrazad HADAD \\ The Bucharest University of Economic Studies, Bucharest, Romania \\ shahrazad.hadad@fabiz.ase.ro \\ Ramona CANTARAGIU \\ The Bucharest University of Economic Studies Bucharest, Romania
}

\begin{abstract}
We present a critical perspective of the current state of development of CSE and SI as fields of study and practice based on a geographical and conceptual mapping of the actors involved in the two fields. Although these concepts are set into motion by different forces on different paths, they converge towards a common apprehension of social business. CSE has no supporting core and it offers scarce and scattered resources for identity formation, while SI benefits from practitioners' attention and is thus developing as a proper field of study. Using this knowledge we anticipate what the future holds for these concepts and offer valuable insights for interested practitioners and academics.
\end{abstract}

Keywords: social entrepreneurship, social intrapreneurship, corporate social entrepreneurship, social entrepreneur, social intrapreneur.

Please cite the article as follows: Hadad, S. and Cantaragiu, R. (2017), "Corporate social entrepreneurship vs. social intrapreneurhsip: same idea, different trajectories?", Management \& Marketing. Challenges for the Knowledge Society, Vol. 12, No. 2, pp. 252276. DOI: $10.1515 /$ mmcks-2017-0016.

\section{Social entrepreneurship and its offspring: corporate social entrepreneurship and social intrapreneurship}

Social entrepreneurship has been the subject of numerous debates regarding the best way in which it can be understood. The most inclusive perspective is the one promoted by Dees (1998) for whom social entrepreneurs play the role of change agents in the social sector by adopting a mission to create and sustain social value, recognizing and pursuing opportunities, innovating, taking risks and displaying a sense of accountability. Boschee and McClurg (2003) emphasize that as entrepreneurs, social entrepreneurs should also have the ability to take the business to a point where it becomes self-sustained by generating earned income. They criticize Dees's (1998) definition because "[i]t allows them (the non-profits) to congratulate themselves for being 'entrepreneurial' without ever seriously pursuing sustainability or self-sufficiency" (p. 2). Dees and Anderson (2006) fought back by redefining the concept and adding the idea of value sustainability and scalability: social entrepreneurs carry "out innovations that blend methods from the worlds of business and philanthropy to create social value that is sustainable and has the potential for large-scale impact" (p. 40). The field of non-profit organizations has provided its own definitions with two of the largest networks of social entrepreneurs around the globe, Skoll and Ashoka coming up with their own take on social entrepreneurs who are "motivated by altruism and a profound desire to promote the growth of equitable civil societies" and transform and shift perceptions acting as change makers 
(ww.ashoka.org). So, their definition goes beyond materialism and achieving material values and refers to the individuals that seek self-actualisation.

Now that social entrepreneurship has gained a strong foothold (although some authors still regard it as being in a pre-paradigmatic state (Jones and Keogh, 2006; Nicholls, 2010; Perez de Mendiguren Castresana, 2013), it is only natural for it to develop offspring, such as the newly coined terms of social intrapreneurship and corporate social entrepreneurship which run with the current thinking that corporate entrepreneurship has in its DNA the genes that carry the social agenda, and these genes need only to become dominant. Social intrapreneurship and corporate social entrepreneurship have not had a long history, but they have proved to be an important resource attractor for those US non-governmental organizations that coined it and have been using it to promote social innovation around the world. As a consequence, NGOs and businesses have rallied around this concept to further their engagement with the facet of capitalism where profit and social value are the desired ends.

According to Hemingway (2005), a social intrapreneur might also be called a corporate social entrepreneur and so far these two terms have sometimes been used interchangeably, but through our literature and practice review we prove that yet not being standalone terms, they differ in meaning and impact. We observe the ways in which some employees are turning socially responsible projects into viable business activities of their corporate employers, a social phenomenon understood from two perspectives: that of the structure and that of the agent. By analysing the trajectory of corporate social entrepreneurship we are able to take a closer look at the structure of the environment in which the social phenomena under scrutiny are taking place, namely the business corporation. The proclaimers embracing this point of view talk about the organization and what needs to be done from the perspective of the organization as a whole. Their discourse targets top-down initiatives. An inverted perspective is offered by following the trajectory of the concept of social intrapreneurship which presents the point of view of corporate employees as they go about their engagement with corporate expansion through social value creation. This bottom-up discourse perfectly complements the one inspired by corporate social entrepreneurship, together creating a complete picture of this social phenomenon.

\section{Research methodology, rationale and objectives}

The discussions presented in this analysis have their foundations in a thorough study of the academic literature, newspaper articles, company websites, blogs, reports published by different NGOs, websites of different organizations, social media pages, and course syllabi that deal with corporate social entrepreneurship or social intrapreneurship. The research method used is qualitative content analysis with a directed approach, the analysis starting with a relevant research finding: social constructivism theory, which is detailed in the following paragraph.

The pool of data used for research has been gathered through extensive searches on the Internet of web pages published in the English language, containing the following keywords: social corporate entrepreneur/ship, social intrapreneur/ship. Thus, the findings of the research present a picture of the English speaking landscape in which the concepts have originated and where 
they have attracted the most attention. The information gathered from these various sources is pieced together to trace the chronological construction of corporate social entrepreneurship and social intrapreneurship whose stories are presented in parallel. This allows us to show that both concepts are fluid and are the results of negotiations between different actors that are trying to promote their own agendas. The histories of these concepts span only over a decade or so, time during which the concepts faced a slow start, which only recently has been replaced by an increased level of interest and activity. By using social constructivism we show the manifold ways in which these concepts have been used with more or less success by different actors (universities, NGOs, media, companies, private individuals) to attract different types of resources (financial, social capital, social recognition, knowledge, personal satisfaction, etc.).

To analyse the concepts of corporate social entrepreneurship and social intrapreneurship, we take as starting point the theory of social constructivism which indicates that different people will have different understandings of the same concept in different areas and different periods. This implies that the meaning of words is not fixed and immutable, but rather fluid and established at the intersection of multiple social interactions. Recently, the field of social entrepreneurship has been increasingly analysed through the lens of social constructivism (Lehner and Kansikas, 2011; Kerlin, 2010; Chell, 2007), which is useful when looking at concepts with culturally, economically, socially, historically and politically variable meanings (Kerlin, 2010), such as the "social enterprise [which] is a contested concept constructed by different actors around competing discourses" (Teasdale, 2010, p. 3). This theoretical perspective has allowed scholars to understand the value the social enterprise idea brings to organizational identity formation (Grant and Dart, 2008), to follow actors' contribution to the meaning of the concept as it changed throughout time (Teasdale, 2010), and to explain its emergence in different countries (Laratta et al., 2011; Park and Wilding, 2013). In a more disruptive manner, social constructivism can also be used to unmask intricate social workings, inspiring certain scholars to critique the way in which certain discourses are taking over in the public sphere and disadvantaging others, such as in the case of the social enterprise mark (Ridley-Duff and Southcombe, 2012).

The first order aims of this research are: a) to map out the different actors that make up corporate social entrepreneurship and social intrapreneurship discourses; b) to describe the activities performed under the umbrella of corporate social entrepreneurship and social intrapreneurship; and c) to gauge if separately their discourses are convergent on a single conceptualization of the two social constructs.

We also ponder over an ontological problem: what is significant about the identity of an organization or individual that considers it/himself a corporate social entrepreneur or a social intrapreneur or in the state of corporate social entrepreneurship or social intrapreneurship? It is not yet clear if these two labels are salient in providing resources for identity creation and this might be a more important research avenue than the one seeking grounds for common or divergent definitions. Although we do not have access to the hows and whys a social actor might choose to identify with these phenomena, we do have at our disposal the discursive resources that they can use in building their identities starting with academic definitions, characterizations and ending with the tips 
printed in magazine articles. As academic researchers, we are also interested in the chances of either one of these concepts of inspiring a field of study, and we use the framework provided by Liles et al. (1995) to compare the prospects of corporate social entrepreneurship and social intrapreneurship as creators of academic disciplines. The final aim regards the distinctiveness of these two social phenomena which is contrasted with what we can call their common nature: are corporate social entrepreneurship and social intrapreneurship the same thing looked at from two different perspectives?

In the research we examine the life stage in which the concepts of corporate social entrepreneurship and social intrapreneurship are situated at the moment and compare their trajectories by following the work of scholars and practitioners. Then we look at the ways in which these concepts are applied in practice and by whom, by focusing on educational services, consulting services, business and non-profit initiatives that inspire today's entrepreneurs and are used to support the development of both fields. The concluding section makes a parallel between the histories of the two concepts and discusses the implications for their future development and for the way in which the social side of commercial entrepreneurship is going to be conceptualized in the next years. In the end, we advocate that these are the two sides of the same coin, but that the coin is fixed so that the probabilities of occurrence of these two sides are unevenly distributed; social intrapreneurship seems to have really taken off and we expect to see many programs addressed to the development of this field, whereas corporate social entrepreneurship is still in its incipient stage.

\section{Corporate social entrepreneurship - current state of knowledge Definitions and meanings of corporate social entrepreneurship}

The term corporate social entrepreneurship was first coined by Hemingway (2004) less than ten years ago in a paper published as part of her dissertation research at Hull University. 10 years have passed since its coinage, but the concept has barely managed to get some traction in the English speaking world, fact proven by the Google (Appendix 1 presents the evolution of activities undertaken in CSE and SI on Google Scholar) search engine which shows only 2.6 million hits for corporate social entrepreneurship (or double that number for corporate social entrepreneur), whereas for a more established concept like social entrepreneurship there are presently more than 76 million Internet pages (Appendix 2 presents a statistic in terms of published articles for both CSE and SI). It is no wonder that corporate social entrepreneurship has yet to be fully accepted as a distinct field of study as the concept still has to battle its forefathers: corporate entrepreneurship, social entrepreneurship and corporate social responsibility to establish its own identity and claim its place in university curricula, scientific classifications and national and international legislation.

The history of, let us call it a rudimentary form of corporate social entrepreneurship dates back a few centuries ago. It crystallized first under the name of philanthropy (according to Ostrander (2007), philanthropy is actually synonymous with social entrepreneurship), it evolved into corporate social responsibility (also referred to as corporate citizenship, triple bottom line, and strategic philanthropy) and it came to be what we today refer to as corporate social entrepreneurship (Zadek 2001; Carroll, 2006; Visser et al., 2007; Googins, et al., 2007). Some scholars argue that corporate social entrepreneurship is the 
most evolved, developed and complex form of corporate social entrepreneurship (Popovici and Muhcina, 2012), while others argue that it is in a class of its own (Austin et al., 2005), making it difficult to trace its origins.

Tasavori (2012) defines corporate social entrepreneurship as "the process of discovering, defining and exploiting opportunities through corporate venturing (internal and external) and innovation as well as strategic renewal which result in social (and environmental) value creation" (p. 13). Wood's (2007) definition focuses on the creation or development of new products, services, or market segments to satisfy social needs, innovation in process or less harmful technologies, or identification of business opportunities to profit as well as addressing a social challenge. Schwab (2008) says that corporate social entrepreneurship is "the transformation of socially responsible principles and ideas into commercial value" (p. 108). To do this, "pioneering enterprises integrate social entrepreneurship into their core activities by channelling their research-and-development capabilities in the direction of socially innovative products and services" (p. 114). In the same vein, Austin et al. (2006) introduce corporate social entrepreneurship as the "process of extending the firm's domain of competence and corresponding opportunity set through innovative leveraging of resources, both within and outside its direct control, aimed at the simultaneous creation of economic and social value". These indications towards expansion have led Larsen (2013) to build on the work of Bode and Santos (2013) and to consider the possibility of a corporate social enterprise built as a subsidiary which will bring to the market an extension of the main brand to change the public's perspective on the whole brand family in a positive way. With this in mind, we can also talk about a corporate social enterprise presented as "a subsidiary whose main mission is to create social impact while operating within a 'not for loss' business model" (Bode and Santos, 2013).

For business consultants, corporate social entrepreneurship lies in the "social space found between corporate social responsibility and the social enterprise" and can be regarded as "a dynamic, flexible, multi-faceted vehicle delivering positive social impact, people and organisation development and new core business opportunities in pursuit of corporate sustainability" (www.socialideation.com). Moreover, it has become a requirement for any business that wishes to remain competitive and it is "the sustained business practice innovating to create economic and social value within an enterprise's core business offerings [involving] frequently, but not always [...] engaging with non-traditional partners such as local communities, tribal groups, producer's associations, and others" (innovate-create.com). The clear emphasis on survival and sustainability, two related concepts, is not that visible in the academic definitions of the term, which focus on profit and social change as the outcomes of corporate social entrepreneurship. There is evidence that approaching corporate social entrepreneurship from the point of view of sustainability makes it a possible selling point for existent organizations, especially if the focus is on the environment: organisations as Vijnne Bardends Logistics (Netherlands) or Babson College (US), enthusiastically claim to have embraced corporate social entrepreneurship by focusing on the impact of their activities on the environment.

But yet the question persists, what does it actually take to be called or classified as a corporate social entrepreneur? By gathering all the existing 
definitions of this kind of people and extracting the themes encountered most often, we can draw a sketch of this type of entrepreneur: (a) he/she is an employee in a corporation; (b) who promotes a socially responsible agenda; (c) to be achieved alongside business profits; (d) in order to solve social problems. With small variations these basic guidelines can be applied to describe the companies that act as corporate social entrepreneurs or the formalization of corporate social entrepreneurs through job positions especially created for them. As an identity marker, this concept has been rarely used by people, the exceptions being Tharani Legatheeswaran of Deloitte, probably the most visible corporate social entrepreneur, Joel Blake, a UK entrepreneur and Ashish Vaidya from an Indian organization. As for corporate social entrepreneurship, this new state of being is accessible to small and large organizations which are willing to (a) leverage internal and external resources in order to (b) expand their markets and (c) create economic and social value.

Besides the problematic nature of defining this almost elusive concept, certain scholars have also tackled the issues of antecedents and outcomes, focusing on environmental factors, organizational factors and organizational results. In a recently published doctoral thesis, Tasavori (2012) argues based on his research on Indian corporations that corporate social entrepreneurship, the motor of social value creation, long-term profitability and legitimacy, depends on demand conditions and stakeholder expectations from the external environment and management support, a network orientation towards social sector organizations and the availability of financial resources from the internal environment. A few years before him, Austin and Refficco (2009) also identified certain key elements to corporate social entrepreneurship such as the enabling environment (open to change, committed to social value creation), the corporate social intrapreneur (a champion, good communicator, creator, catalyst, contributor, coordinator and calculator, see Austin et al., 2005), corporate purpose (value-based organization), value creation and double return (shift towards optimizing revenues to stakeholders) and cogenerating value (inter and intra-sectorial partnerships). Other attempts have been directed towards the adaptation and validation of measurement instruments that would identify the opportunities for corporate social entrepreneurship in particular settings such as the Australian elder care industry (Hazelton and Murray Gillin, 2011). However, the only publicly available set of guidelines for enabling corporate social entrepreneurship in an organization has been drafted by Crets (2012) and it focuses on the issue of environmentally sustainable business, recycling and reducing waste, which does not produce any valuable insights into the how of corporate social entrepreneurship.

\section{Activities and actors involved with corporate social entrepreneurship Universities and other providers of educational services}

Although there are only two monographs on corporate social entrepreneurship (Hemingway, 2013; Bonin and Thomes, 2013, where corporate social entrepreneurship is presented as a fad imbued with a paternalistic mentality), a couple of dictionary entries (Wood, 2007; Idowu et al., 2013) and a small number of scientific and business articles on the subject, universities and other educational organizations have started to provide courses in this area. It is very 
probable that these universities use case studies like the ones published by SEKN (the Social enterprise Knowledge Network) to help students understand the intricacies of corporate social entrepreneurship, which explains the interest expressed by Carrick and Santos (2013), "[h]aving cases exploring the launching and growth of corporate social entrepreneurship initiatives within large firms would be fantastic, in particular for business students who are likely to end up working at multinationals." (p. 11).

Most study programs which revolve around the theories of social entrepreneurship have started to offer at least some courses, if not the opportunity to specialize in corporate social entrepreneurship. One exemplary case is that of the Trinity Saint David University of Wales which provides its MBA students with a module centred on corporate social entrepreneurship. This university works with the Community Learning Research Fellows to design and carry out research activities in which a student is partnered with a faculty member and a community member or an organization to solve a social problem. This way Eddy Oketch can study the possibility of using the local community gardens to solve the problem of youth unemployment by applying the principles of corporate social entrepreneurship. At the Berlin Steinbeis University, the graduates of the Master of Arts in Responsible Management can choose to work on social business projects based on corporate social entrepreneurship which can then be supported by their Student and Alumni network. Furthermore, there are also short-term training sessions, such as the one-day training focused on corporate social entrepreneurship, business model and business development proposed by i-genius in partnership with the Loop Global Management and CASoft in Lahore, Pakistan or the program proposed by Meirc Training and Consulting in Dubai which deals with corporate entrepreneurship and has a section dedicated to corporate social entrepreneurship in the public sector.

Besides teaching the principles of corporate social entrepreneurship, universities also have the possibility to become actively involved in the practice of corporate social entrepreneurship, and Babson College boasts itself with being the "leader in the field of corporate social entrepreneurship and environmental sustainability" (Babson College, 2014, p. 8).

The scholars employed by universities are also the ones who are advancing the field through empirical studies and conceptual papers in which they assemble the social in such a way as to define and explore this new behaviour by focusing on the interplay between corporations and individuals. Some focus on the individual's characteristics (such as the studies conducted by Hemingway $(2005,2013))$, while others see the individuals as part of a conglomerate of factors which combine to create an institutional behaviour (like the conceptual paper written by Austin and Reficco (2009)). These are studies performed by British and American scholars on the Western workforce who has reached a level of post-modern development signalled by the embrace of postmaterialist values such as autonomy and self-expression (Inglehart, 2000).

\section{Management consulting companies}

The Center for Innovation in Social Entrepreneurship, a US entity founded in 2010, offers consultancy for multinationals, NGOs and governmental bodies in multiple areas, among which we encounter corporate social entrepreneurship. Their support covers the following areas: (i) social innovation strategies; (ii) 
stakeholder identification, mapping, assessment, and engagement; (iii) program design, implementation support and results evaluation; and (iv) strategic communications support. However, according to the information provided on their website, the centre has yet to be successful in obtaining a contract for corporate social entrepreneurship consultancy. In the UK, we find Imaginals Ltd, founded in 2009, a consulting firm that specializes in corporate social entrepreneurship and Socialideation ${ }^{\mathrm{TM}}$ which works with private, commercial organizations to broker and facilitate partnerships and collaborative ventures, develop their social strategy and ethos in order to help them go beyond the traditional CSR practices and 'be more social' (www.socialideation.com). In 2011, liveinnovation ${ }^{\mathrm{TM}}$ was added to the group of management consulting companies focusing on shared value creation, brokering collaboration between the corporate and the social enterprise sector and developing the business model of social enterprises, thus bringing the two fields closer together. Although this company boasts its ability to make an organization 'be more social', these management consultants apply the same techniques we would apply if we wanted to expand the market for an ordinary business only profit oriented. This points to the fact that clear practices in the field of corporate social entrepreneurship have yet to be established and consultants are borrowing ideas from business consulting, social media consulting and public relations to name just a few.

The consulting industry is mostly focused on selling its services by advertising the spectacular empowerment that corporate social entrepreneurship can bring to an organization: “(a) the development of a corporate social strategy where none exists; (b) commercialization of existing social initiatives; (c) the development of social angles to commercial initiatives (d) support of major infrastructure projects; (e) collaborative ventures with external stakeholders, e.g. customers, suppliers, social enterprise, public sector, agencies etc.; (f) incubation of social enterprise from idea to maturity; (g) conversion of existing initiatives and projects into social enterprise; and $h$ ) other breakthrough change initiatives as yet undefined that will fall out of the innovation process" (www.socialideation.com).

\section{NGOs}

The concept of corporate social entrepreneurship seems to be equally attractive to Western developed countries, as well as South American (Trinidad and Tobago) or Asian countries. For example, in 2011, in Afghanistan, Edwin Hauwert has initiated a movement of "various young creative and social minds" that ended up founding the Young Social Entrepreneurs for Afghanistan (YSEA) community with the mission to "achieve sustainable growth and prosperity in Afghanistan through corporate social entrepreneurship" by contributing to the development of the following areas: "sesame oil enhancement, purified water generator, splendour education system, advance communication technologies, sustainable energy sources". In Western Asia, North-Korean Sung Tack Kim and his fellows have established the Next Society Foundation with the sole purpose to spread the principles of corporate social responsibility and corporate social entrepreneurship and rid the world of famine and poverty. Their focus is on the mechanisms of the social enterprise that would help disadvantaged populations, like those in Africa and other Third World Countries, to achieve self-sufficiency 
and sustainable capacity so that they become part of those who are benefiting from economic progress.

\section{Media}

In an article published in the Trinidad Express Newspapers, Braithwaite (2011) makes an appeal for companies to conduct themselves in the manner required by the principles of corporate social entrepreneurship. He trusts that agencies and corporations which are state-owned will be more inclined to start worrying about the social conditions of the local communities from Trinidad and Tobago which are faced with juvenile delinquency and gang violence, as "corporate social entrepreneurship provides the framework for more sustainable communitydevelopment programmes and more responsible corporate citizenship".

\section{Rounding up the results on corporate social entrepreneurship}

The research conducted on the scientific literature, newspaper articles, specialized reports published by different NGOs or government, websites of different organizations, and social media pages reveals that the academic interest in corporate social entrepreneurship has manifested starting with 2004 and it has been increasing ever since (Figure 1).

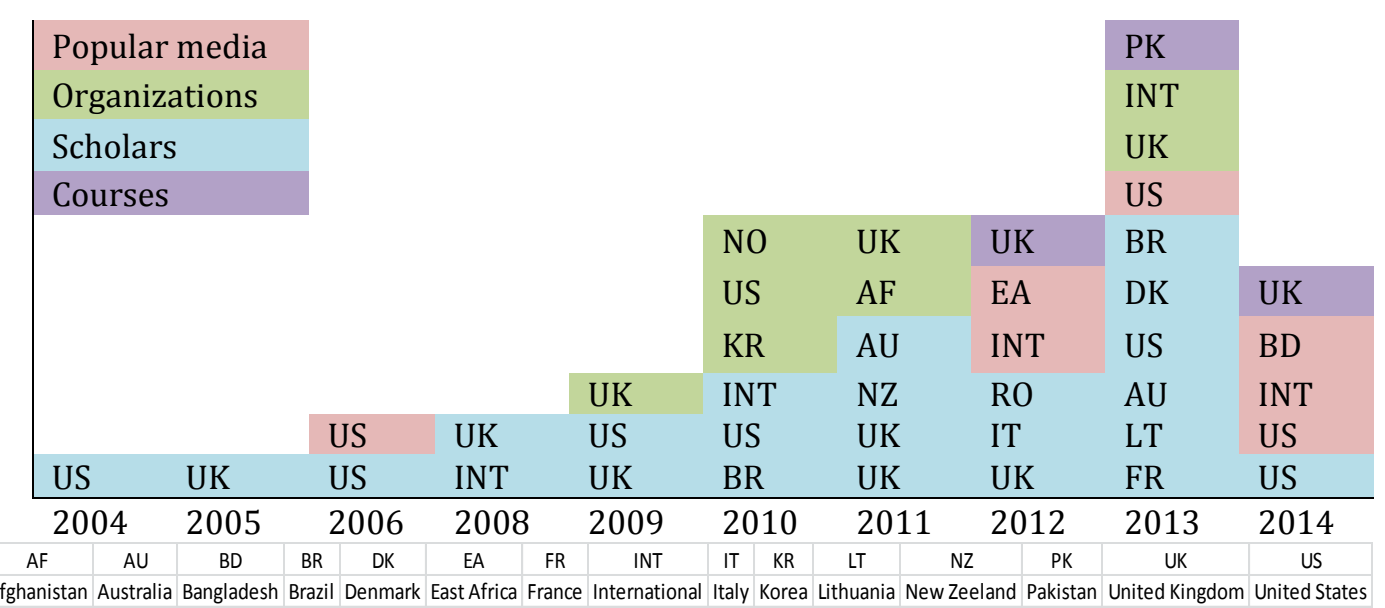

Figure 1. Corporate social entrepreneurship activities in space-time coordinates

Source: Authors' own findings.

Around half of the research published until now belongs to scholars affiliated to UK and US institutions, while the other half is concentrated in the rest of Europe. Although geographically the scholars are close, we can be spot only faint connections between their research agendas.

The second most popular category of interested actors is comprised of those who have founded either management consulting companies or NGOs. The countries that show the most active scientific interest are also those that house the initiatives that approach corporate social entrepreneurship from a commercial point of view. The concept has been sporadically presented within media articles and has also served as inspiration for courses and other educational events. 


\section{Social intrapreneurship - current state of knowledge Definitions and meanings of social intrapreneurship}

The term intrapreneur was coined in 1978 by Gifford and Libba Pinchot. In 2006, Mair and Marti referred to social intrapreneurship as being social entrepreneurship in a new or an already established organisation. Elkington and Love claim to have actually coined the social intrapreneur term in 2008 when they published The Social Intrapreneur Report. As Google (Appendix 1 presents the evolution of activities undertaken in CSE and SI on Google Scholar) searches show it, the concept of social intrapreneur has barely surfaced with a hit of 139 000 results. Its popularity in the academia is just as faint because there are relatively few scientific articles written on this subject and we found the majority of posts related to social intrapreneurs in business magazines (such as Forbes, The Guardian, blogs) mostly written by practitioners (Appendix 2 presents a statistic in terms of published articles for both CSE and SI).

In the previously mentioned research report published in 2008 on social intrapreneurship, Elkington, the co-founder of SustainAbility explains the motivation behind their inquiry as stemming from previous research on social entrepreneurs and their connections with the already established business sector. They claim that the social entrepreneurs they discovered in companies such as Accenture, Banco Real, Coca-Cola, Ford, Morgan-Stanley and Nike "were still struggling to find a common identity, even if they share(d) a common purpose" (Grayson et al., 2011, p. 1). It is widely acknowledged that giving a name to a social phenomenon, in fact, gives people the resources necessary to unite and construct a self-identity which can be easily understood and accepted by others. Hence, there are people today who present themselves as social intrapreneurs in their professional CVs and who seek to find others of the same kind to unite forces and share personal experiences with (e.g. the personal page of James Espiritu at socialintrapreneur.weebly.com; Skoll World Forum 2013 participants: Regula Schegg - Strategic Business Developer for Hilti Foundation, James Inglesby - Category Manager for Unilever Nigerian and CoFounder/Director of Clean Team Ghana, and Aslihan Denizkurdu - Director of Corporate Strategy at Citigroup, who publicly shared their experiences referring to themselves as social intrepreneurs; the three of them were Aspen First Movers Fellows). This kind of people is constructed through the various researches that have been conducted and which are on the rise and through all the different other resources coming from practitioners which we will present in this chapter.

For this kind to be powerful enough to bring about changes in the social world, it has to be differentiated enough from other kinds of people to stand on its own and provide a basis for self-identification and public policies. As such, social intrapreneurs are contrasted with social entrepreneurs on the one hand, and with their employed counterparts working in corporate social responsibility departments or acting as corporate volunteers and green team members. Their distinctive nature comes from two defining dimensions: one, they act within already established business boundaries, and two, they are focused on bringing profits to their companies.

In "The Social Intrapreneur - A Field Guide for Corporate Changemakers" (SustainAbility, 2008, p. 4), the social intrapreneur is defined as "a) someone who works inside major corporations or organisations to develop and promote 
practical solutions to social or environmental challenges where progress is currently stalled by market failures; b) someone who applies the principles of social entrepreneurship inside a major organisation. c) one characterised by an 'insider-outsider' mind-set and approach." Therefore, we can identify the prerequisites of social intrapreneurship as being: employee, corporation, solution, social/environmental challenge, progress. According to Stewart (2013), the social intrapreneur is an employee who uses corporate politics to get disruptive ideas to market and to more customers sooner, with greater environmental or social impact. Synthetizing the already designed definitions, we identify a social intrapreneur as being an employee who leverages corporate politics to come up with a practical/innovative solution to a social problem to create social value and profits. As for social intrapreneurship, this is the action of a social intrapreneur who seeks to outreach the community in order to blend societal and business values as to address social challenges.

Social intrapreneurs are hailed as a "rare breed" (Simms, 2008) made up of specimens difficult to identify in the social world because "they can be anywhere in the corporation; there is no set route to social intrapreneurship" (idem) which can be equated with saying that social scientists and the society at large for that matter have yet to establish clear boundaries and investigative methods for this kind of people. However, one solution is to encourage people to start identifying themselves as such by providing guidelines for the process in the form of newspaper articles entitled "How to be a social intrapreneur: persistence, resilience and patience" (Carvalho, 2013), "5 signs you may be a social intrapreneur" (Satiani, 2012) or "I am a social intrapreneur. You may be, too!" (Vanides, 2010). Moreover, as the concept gains traction, different types of social intrapreneurs tend to appear as in Grayson et al. (2011) where they talk about resigned, frustrated, emergent, quiet, tolerated and embraced social intrapreneurs, nuances which highlight the fact that this kind is not homogenous and static, but always in the making in varying degrees, the same as Hemingway's (2005) corporate social entrepreneurs were active or frustrated.

Nonetheless, this "'lost tribe' of social innovators embedded in corporate America" needs to be found and funded in order to "change the way the world does business" (Townsend, 2012). Some might say we need to question the current outburst of faith in the role that social intrapreneurs are going to play in designing a new capitalism and, consequently, a new world, because it seems that many have a short life span and most get swallowed up by the existing organizational system, but instead we call these people to 'rise' because their time has come (p, 2013). As one social intrapreneur says, "social intrapreneurship is not an occasional phenomenon, but a real trend" (Teixeira de Morais cited in Carvalho, 2013), stimulated by changes in the labour market where the high professionalism and concern for sustainability of the work force provides a ripe environment for this phenomenon.

There is also resistance to the identification with this type of "preneur", as Bob Annibale (cited in Simms, 2008) says: "I never thought of myself as social intrapreneur and that's not how I label what we do. It's about disruptive innovation and changing the paradigm of a defined landscape. I don't use emotive language: I don't talk about 'beneficiaries' but about serving the needs of a new client sector". Another good example is the following person whose name has not been revealed, who, during a meeting with Gib Bulloch, Executive 
Director, Accenture Development Partnerships, described herself: "I graduated from college at 22 and wanted to join the Peace Corps - but my parents wouldn't let me. So I became a banker instead. On completing my MBA from Wharton several years later I thought again about my Peace Corps dream. Friends and family were discouraging so I went back to the bank with an idea to set up a Social Investment Fund. They accepted a business case for a $\$ 250 \mathrm{~m}$ initial investment and the new CEO I recruited starts next week" and the director concluded "You are a social intrapreneur", while her reply was "A social what?" (Bulloch, 2013). Many of them are practitioners having outstanding performances without even knowing it. A social intrapreneur is not yet a job title and does not have a well-defined job description, but it is a behaviour/attitude that can be employed by anyone. As we will debate further on, her not knowing about this category of "preneurs" might turn out to be beneficial for her because she will not be affected by this categorisation, and detrimental from the point of view of restricting her "specialized networking".

\section{Activities and actors involved with social intrapreneurship NGOs, organisations and institutes}

The trend today appears to be set by those organizations which have already established a clear understanding of this social phenomenon and are now seeking to provide support in form of knowledge and funds for social intrapreneurs worldwide. The European Business Network for Corporate Social Responsibility, in partnership with Ashoka and the BMW Foundation has launched the European Social Intrapreneurship Programme which will provide companies with a guide on best practices in fostering social intrapreneurship and will set up an award to discover and mobilize resources in favour of social intrapreneurs. In parallel, Ashoka Changemakers are also the organizers of the League of intrapreneurs competition which offers media and social support for the most outstanding business ideas with social impact through partnerships with Fast Company, CO.EXIST and Accenture Development Partnerships.

Other organizations like BeDo in the US, the Centre for Social Brilliance in the UK (in partnership with the international law firm Reed Smith LLP) or the Singapore Institute of Management provide opportunities for people interested in social intrapreneurship topics to participate in social gatherings where expert speakers and experienced entrepreneurs foster an environment meant to create long-lasting networks of like-minded peers.

\section{Universities and other educational providers}

Universities have adapted their curricula much slower, and there are still only a handful of institutions offering courses in social intrapreneurship, such as Northwestern University, The Ross School of Business from the University of Michigan which plans to become the primary attractor of socially conscious MBA students and The Aspen Institute which gives support and training to social intrapreneurs through its First Movers Fellowship Program.

In 2012, Accenture, Business Fights Poverty and Leadership Laboratories created "The Intrapreneur Lab" - a 3 day + 3 month programme designed to help employees in large MNCs develop profitable innovations that create social impact. The idea was put into practice in October 2013 at the Saïd Business School (Oxford) and it was a tremendous success having participants from 
Barclays, GSK \& Novartis and inspirational guest faculty. They managed to confirm two Labs for 2014, one in May hosted by Cornel University in New York and one in October hosted by Saïd Business School, Oxford.

The Makers Institute is a grass roots initiative of the Be Social Change community that addresses a gap unfilled by traditional business schools: the training that employees looking to have a social impact by practicing their profession need in order to be successful. Accordingly, they provide majors in Social Entrepreneurship, Social Intrapreneurship and Civic Innovation through online courses offered in partnership with other educational organizations such as Lean Startup Machine, ReWork, B Corp, Reboot, Center for Social Innovation and Schoology among others. The Institute for Technology and Social Change has teamed up with Ashoka Changemakers in order to deliver the one month online course "Social Intrapreneurship - Innovation within Institutions" facilitated by Joseph Agoada, the course is not only intended to immerse the employees/students into concept notes, budgeting and pitching, it also intends to provide personalized feedback for each participant and facilitate a number of opportunities for participants to network and get in touch with like-minded course-mates. The teaching methods that they are going to use are one of the most varied: dynamic learning environment with a number of real-world case studies, custom animations and video tutorials, live sessions with leading social intrapreneurs, and practical simulations to apply new skills and strategies (TechChange, 2014).

\section{Media}

In an interview for The Guardian, Geoff McDonald (Conniff, 2011), global vice president of human resources at Unilever, said that it is neither the churches nor the governments that are going to make the change in the world, but companies like $P \& G$, Unilever, Nestle and others. What is very interesting to be observed is that, as us, Geoff also makes the distinction between the social entrepreneur and the social intrapreneur, claiming that they have to seek each other out such as to make meaningful, sustainable and scalable contributions to the society, while their mutual interests (partnerships) should act as a compass in their quest. Recently, Forbes (Ashoka, 2014) has published an article on "2014's Most Valuable Employee: The Social Intrapreneur" in which Joseph Agoada upholds the idea according to which the social intrapreneur finds himself at the intersection of innovation, social good and enterprise and, we might add resources, where he could ally with the social entrepreneur who lacks the resources and network for high level impact in order to become the actual change.

\section{Rounding up results on social intrapreneurship}

Figure 2 sums up that the term of social intrapreneurship emerged in 2004 in a work in progress, in academic research, and between 2004 and 2008 it gained recognition in the academia. Starting with 2008 till the present, it has been drawing the attention of the media which constantly writes about social intrapreneurs, and also of the practitioners who have become more and more involved. Regardless of the geographical closeness of the scholars, their research does not seem to be connected. This conclusion has been drawn cautiously because some of the articles written in the academia (for social 
intrapreneurship) were not fully available due to database restriction therefore they were only used to provide information about the affiliations of the authors such as to indicate their geographic area.

On the other hand, the practitioners tend to team up for delivering different kind of events: leagues, seminars and courses, programmes. Although their actions seem few, in terms of impact, they even manage to unite continents confirming once again the idea that in practice everything moves faster. There have been few initiatives of transposing the concept into courses (all concentrated in the US). We foresee a strong intensification of this "breed" in the next years to come.

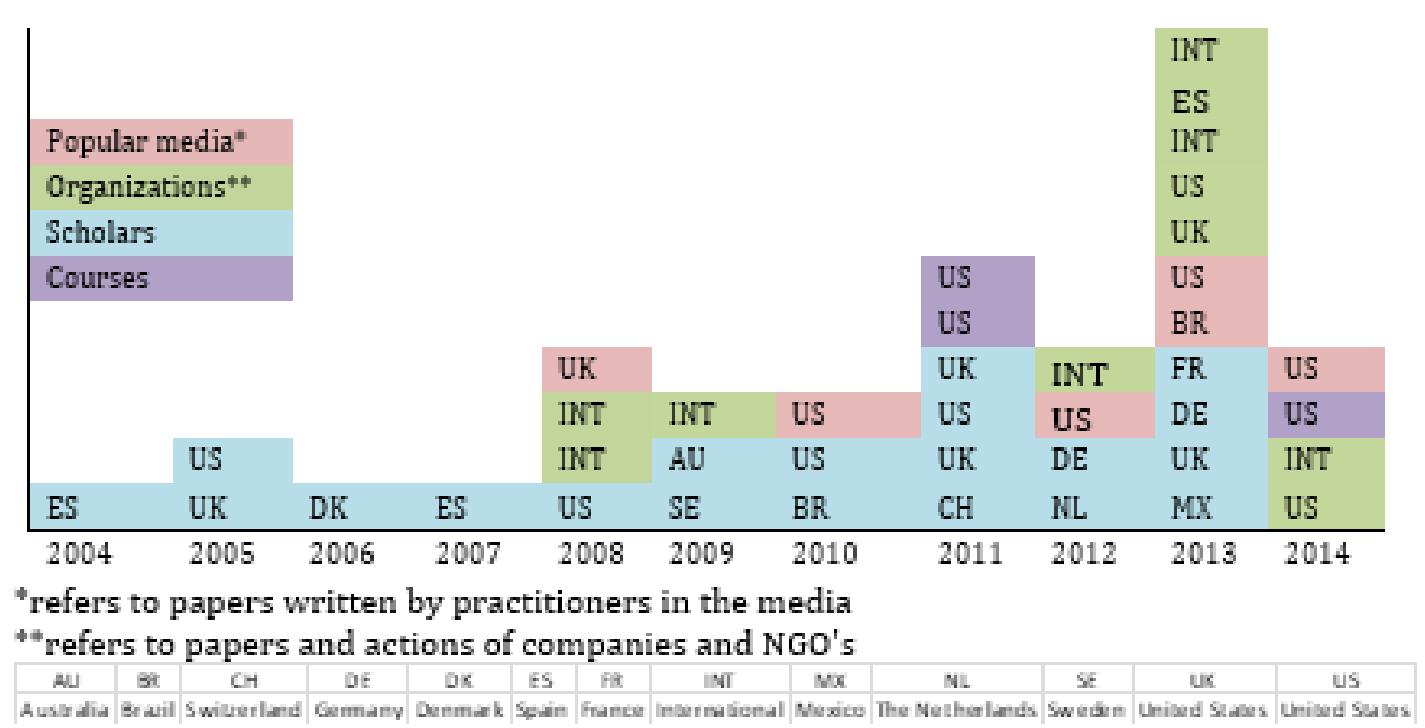

Figure 2. Social intrapreneurship activities in space-time coordinates

Source: Author's own findings.

\section{A parallel between corporate social entrepreneurship and social intrapreneurship}

The question that we need to answer now is whether we are dealing with the birth of a new kind of people or organizations or these are simply concepts that build on existing knowledge and have no clear delimitations from already popular concepts such as social entrepreneur, corporate citizen etc. In the case of corporate social entrepreneurship, the field is not dominated by any group of people working to promote the concept, a reality substantiated by the fact that the instances when corporate social entrepreneurship appears are few in number and spread all over the globe, with no particular centre of gravity which could pull resources together to create a common discourse. As such, companies and their employees are left on their own to try to find their way towards corporate social entrepreneurship and although we can find people who are either identifying themselves as corporate social entrepreneurs or are being categorized as such by others, the feeling one gets is that the concept is too vague to create a clear sense of belonging. There are few opportunities for companies and employees to gain specific knowledge in the field of corporate social entrepreneurship as universities and other institutional providers, as well as 
consulting companies are moving slowly and there are no actors looking to financially sustain corporate social entrepreneurship endeavours.

On the other hand, social intrapreneurship creates a new kind of people building on previously existing concepts, though there is not a clearly established framework of principles (Figure 3). The field is dominated by a group of NGO's and companies whose relationships and actions of social intrapreneurship are depicted in the figure below: the circles represent programmes/actions/initiatives/papers, while the rectangles represent organisations, companies, NGO's. The media has managed to create a frenzy in regards to the emergence of this new breed, thing that can either represent an incentive for those corporate employees who want to follow the latest trends, or a constraint for those employees who internalise society's expectations even though these are dissonant with their own wishes. The prospective adopters of this trend are the beneficiaries of multiple resources (money, knowledge, social recognition to name just a few) coming from various sources (the business sector and the third sector, the public sector is not yet involved).

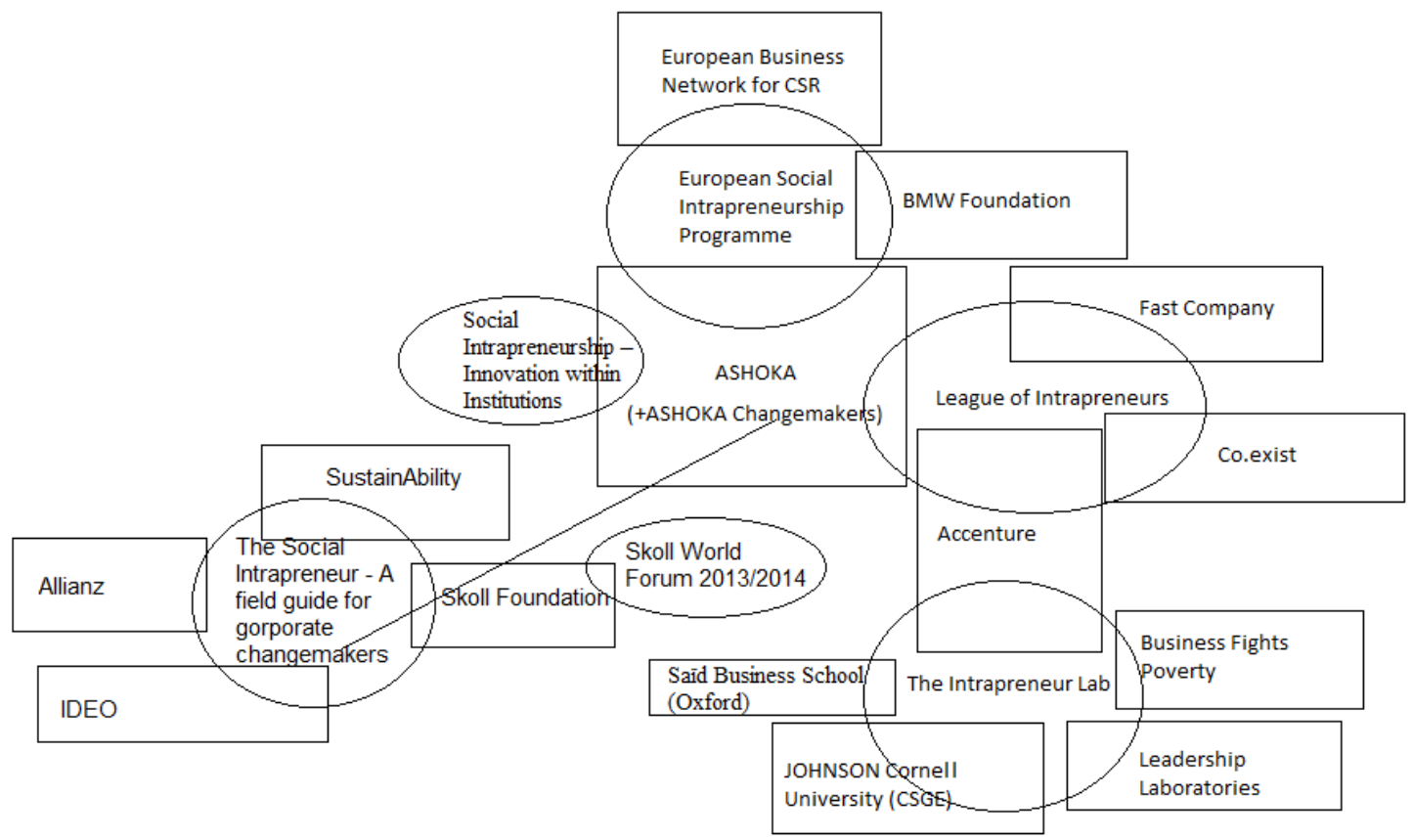

Figure 3. Links between actions of social intrapreneurship

Source: Author's own design.

The second question to ask is: considering the amount of interest coming from the academic community, do these concepts represent starting grounds for sound academic disciplines or will simply become incorporated in other fields of study such as business ethics, social entrepreneurship, corporate social responsibility and so on? The building blocks of any academic discipline are represented by a clear focus on a particular object of study, a paradigm, some reference disciplines, specific research agenda based on specific principles and practices, and education and professionalism (Liles et al., 1995). The characteristics of corporate social entrepreneurship and social intrapreneurship are presented in parallel in Table 1. 
Table 1. Corporate social entrepreneurship and social intrapreneurship as scientific disciplines

\begin{tabular}{|c|c|c|}
\hline $\begin{array}{l}\text { Characteristics } r \text { of } \\
\text { scientific disciplines } \\
\text { (adapted from Liles et } \\
\text { al., 1995) }\end{array}$ & $\begin{array}{l}\text { Corporate } \\
\text { entrepreneur/ship }\end{array}$ & Social intrapreneur/ship \\
\hline Field of focus & $\begin{array}{l}\text { Fragmented (business model, } \\
\text { CSR strategy, brand expansion) }\end{array}$ & $\begin{array}{l}\text { Employees acting in accordance } \\
\text { with the principles of social } \\
\text { entrepreneurship }\end{array}$ \\
\hline Paradigm/World view & \multicolumn{2}{|c|}{$\begin{array}{l}\text { 'doing well by doing good' } \\
\text { The best adaptive behaviour of businesses and of individuals is to } \\
\text { transform socially responsible principles and ideas into } \\
\text { commercial value. }\end{array}$} \\
\hline Reference disciplines & $\begin{array}{l}\text { social entrepreneurship, } \\
\text { corporate social responsibility, } \\
\text { business ethics, sustainable } \\
\text { development }\end{array}$ & $\begin{array}{lr}\text { social entrepreneurship, } \\
\text { entrepreneurship, } & \text { business } \\
\begin{array}{l}\text { development, } \\
\text { citizenship }\end{array} & \text { corporate } \\
\end{array}$ \\
\hline Practice and principles & $\begin{array}{l}\text { Practices - borrowed from } \\
\text { other fields } \\
\text { Principles: - shared value } \\
\text { creation } \\
\text { - market expansion by focusing } \\
\text { on social issues } \\
\text { - innovative identification and } \\
\text { exploitation of social } \\
\text { opportunities }\end{array}$ & $\begin{array}{l}\text { Practices - presented in Grayson } \\
\text { et al. (2011) } \\
\text { Principles: - societal value } \\
\text { creation } \\
\text { - preserving nature and serving } \\
\text { others } \\
\text { - higher social conscience and a } \\
\text { transcendent self }\end{array}$ \\
\hline Research agenda & No clear research agenda & $\begin{array}{l}\text { Examining how individuals, } \\
\text { businesses and societal } \\
\text { institutions interact to create } \\
\text { sustainable social value } \\
\text { Features of the enabling } \\
\text { environments of SI } \\
\text { Guide on best practices in } \\
\text { fostering SI }\end{array}$ \\
\hline $\begin{array}{l}\text { Education } \\
\text { professionalism }\end{array}$ & $\begin{array}{l}\text { Some courses, frail institutional } \\
\text { support }\end{array}$ & $\begin{array}{l}\text { High institutional support, } \\
\text { courses, support groups }\end{array}$ \\
\hline
\end{tabular}

At first glance, social intrapreneurship seems to have been endowed with far greater chances of becoming a standalone discipline taught in business schools around the world. Therefore, although they share the same world view and most of their reference disciplines, corporate social entrepreneurship is dissipated into various strands, while social intrapreneurship has found a focus that inspired a rich research agenda and attracted high institutional interest. As per their future, if corporate social entrepreneurship were to become a discipline, its focus could be on the study of new business models with a double or tipple bottom line. Until now corporate social entrepreneurship has been linked to sustainable growth, environmental protection, profit making by accessing the wealth found at the BoP (Prahalad, 2006), brand marketing, social business models and many others. These associations make the concept useful for any individual or organization looking to infuse their actions with social and environmental care, but create a confusing portrait of the concept. In order to overcome this state of emergence, the new discipline has to be built in such a way as to account for all the manifestations of the phenomenon of corporate social entrepreneurship, a set of basic knowledge about corporate social 
entrepreneurship has to be established and social actors have to identify themselves as members of the new community. As we mentioned before, there is no clear institutional support, which combined with the other characteristics, leads us to believe that corporate social entrepreneurship will have to wait a few more years before becoming an academic discipline in its own right, whereas we can already talk about social intrapreneurship courses, and sooner rather than later we will witness the rise of university graduates with majors in social intrapreneurship.

The final and main question of the present discussion concerns the similarities and differences between the two concepts. As we have previously established, they start from the same concept of social business which makes them look, at least on paper, interchangeable. Because they have travelled on different paths, we concentrate on the nuances that could explain how the same idea encapsulated in two different shapes can be grasped in distinct manners by society. Table 2 reflects our ideas regarding the potential differentiators that may have some influence on the concepts' popularity: direction of initiatives, type of governance, addressee, value orientation and actor/behaviour.

Table 2. Differences between corporate social entrepreneurship and social intrapreneurship

\begin{tabular}{|l|l|ll|}
\hline Differentiators & $\begin{array}{l}\text { Corporate Social } \\
\text { Entrepreneurship }\end{array}$ & Social Intrapreneurship \\
\hline $\begin{array}{l}\text { Direction of } \\
\text { initiatives }\end{array}$ & Top-down & Bottom-up & \\
\hline $\begin{array}{l}\text { Type } \\
\text { governance }\end{array}$ & of & Decentralised & \\
\hline Addressee & $\begin{array}{l}\text { Primarily top managers }+ \\
\text { middle managers }\end{array}$ & $\begin{array}{l}\text { All levels of management + non- } \\
\text { managerial employees }\end{array}$ \\
\hline $\begin{array}{l}\text { Value } \\
\text { orientation }\end{array}$ & $\begin{array}{l}\text { Socially responsible values } \\
\text { of the organisation }\end{array}$ & $\begin{array}{l}\text { Post-materialistic values of the } \\
\text { individuals }\end{array}$ \\
\hline Actor/behaviour & $\begin{array}{l}\text { Predominantly as } \\
\text { corporate } \\
\text { entrepreneurship }\end{array}$ & $\begin{array}{l}\text { Predominantly used as social } \\
\text { intrapreneur }\end{array}$ \\
\hline
\end{tabular}

Source: Author's own findings.

There are far less instances of the term corporate social entrepreneur, which refers to the identity of the person, than of the term indicating a behaviour "corporate social entrepreneurship on the Web today, and from a semantic point of view this suggests that corporate social entrepreneurship is regarded as an action to be taken in order to reach a certain goal, making it a macro-term associated with large bodies of persons, such as non-governmental organizations or corporations. On the other hand, the social intrapreneur is a very fashionable identity tag which depicts behaviour and it is vastly more popular than the term social intrapreneurship, which indicates that it is a micro-term referring mostly to individuals pursuing their personal goals.

Therefore, we think that the persons who are likely to engage in social intrapreneurship activities are those who have reached a certain level of spirituality and self-accomplishment, that are satisfied with their lives and they want to take it to the next level by improving the lives of others. Thus, all these differentiators which highlight the individual and his/her agency and desire for 
to reach his/her true potential in the case of social intrapreneurship and the business organization acting strategically to transform its social mission into profits in the case of corporate social entrepreneurs explain the attraction that the public has towards the former concept and the lack of interest it has shown to the latter. We are still living in a century of the self, and our research shows that it is easier to attract resources while using the label which emphasis the empowered employee and not the profiteering organization. To conclude we would like to illustrate this finding by making use of the example of the Socialideation management consulting company's business case. The owners of the business started in 2013 with a clearly stated focus on corporate social entrepreneurship, which lasted until 2014, when this label has been replaced by social intrapreneurship, all other things unaltered, to end up in 2015 to use the terminology Social Venture Management Zone, as can be seen in Figure 4.

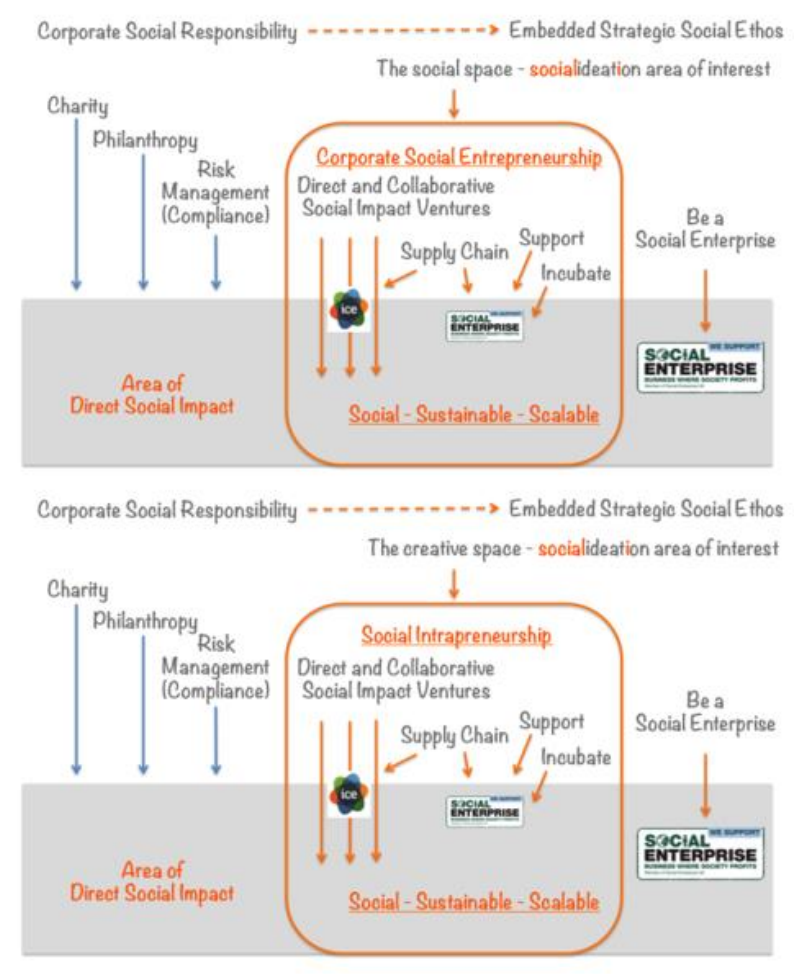

socialideation $^{\mathrm{rm}}$

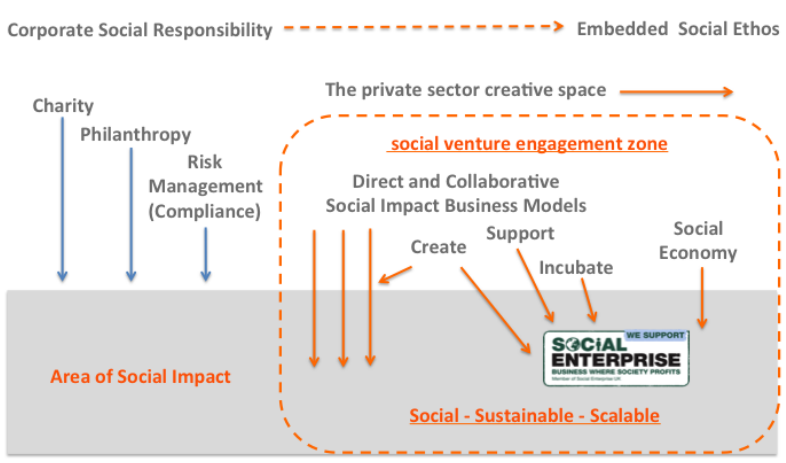

Figure 4. Business adaptation to social realities - 2013, 2014 and 2015

Source: www.socialideation.com 
We cannot tell what the future holds, but we anticipate that more of the adopters of corporate social entrepreneurship will shift towards social intrapreneurship and this concept will soon be the subject of public policies.

\section{References}

Ashoka (2014), “2014's most valuable employee: The social intrapreneur", Forbes, 24 January, available at: www.forbes.com/sites/ashoka/2014/01/24/ 2014s-most-valuableemployee-the-social-intrapreneur (accessed 5 May 2014).

Austin, J.E., Leonard, H.., Reficco, E. and Wei-Skillern, J. (2005), "Social Entrepreneurship: It's For Corporations, Too", in Nicholls, A. (Ed.), Social Entrepreneurship: New Paradigms of Sustainable Social Change, Oxford University Press, Oxford, GB, pp. 169-80.

Austin, J.E., Leonard, H., Reficco, E,. and Wei-Skillern, J. (2006), “Corporate Social Entrepreneurship: The New Frontier", in Epstein, M. and Hanson, K. (Eds.), The Accountable Corporation. Volume 3: Corporate Social Responsibility, Praeger, Westport, CT.

Austin, J.E. and Reficco, E. (2005), “Corporate social entrepreneurship”, working paper, No. 09-101, Harvard Business School, Harvard University, Boston.

Babson College (2014), "Commencement", available at: www.babson.edu/newsevents/events/commencement/Documents/commencement-2014undergraduate.pdf (accessed 12 April 2014).

Bode, C.S. and Santos, F.M. (2013), "The organisational foundations of corporate social entrepreneurship", Working paper, No. 2013/07/EFE/ST/ICE, INSEAD, Paris.

Bonin, H. and Thomes, P. (Eds.) (2013), Old paternalism, new paternalism, postpaternalism, Peter Lang, New York, NY.

Boschee, J. and McClurg, J. (2003), "Toward a better understanding of social entrepreneurship: Some important distinctions", Social Enterprise Alliance, available at: http://www.setoolbelt.org/resources/180 (accessed 7 April 2014).

Braithwaite, R. (2011), "Embracing social entrepreneurship", Trinidad Express Newspapers, 12 October, available at: www.trinidadexpress.com /commentaries/Embracing_social_entrepreneurship-132118463.html (accessed March 4 2014).

Bulloch, G. (2013), "Harnessing the herd - Could social intrapreneurs represent a "trojan horse" strategy for charities", Business Fights Poverty, 24 March, available at: community.businessfightspoverty.org/profiles/blogs/gibbulloch-harnessing-the-herd (accessed at 3 April 2014).

Carrick, A.M. and Santos, F., (2013), "Nuru Energy”, Oikos Case Quarterly, Winter, No. 9, pp. 10-11.

Carroll, A.B. (2006), "Corporate Social Responsibility: A Historical Perspective", in Epstein, M. and Hanson, K. (Eds.), The Accountable Corporation. Volume 3: Corporate Social Responsibility, Praeger, Westport, CT.

Carvalho, I. (2013), "How to be a social intrapreneur: persistence, resilience, and patience", Co.Exist, 15 May, available at: www.fastcoexist.com/1682063 /how-to-be-a-social-intrapreneur-persistence-resilience-and-patience (accessed 6 April 2014). 
Chell, E. (2007), "Social enterprise and entrepreneurship: Towards a convergent theory of the entrepreneurial process", International Small Business Journal, Vol. 25, No. 1, pp. 5-26.

Conniff, S. (2011), "A guide to 'social intrapreneurs' and where to find them", The Guardian, 31 January, available at: www.theguardian.com/socialenterprise-network/2011/jan/31/social-entrepreneur-business-insiderschange (accessed 11 April 2014).

Crets, S., (2012), “Enterprise 2020: don't stifle your corporate social entrepreneur", CSRWire, 22 May, available at: www.csrwire.com/blog/posts/415-enterprise-2020-dont-stifle-yourcorporate-social-entrepreneur (accessed 6 April 2014).

Dees, J.G. (1998), “Enterprising nonprofits”, Harvard Business Review, Vol. 76, No. 1, pp. 55-67.

Dees, J.G. and Anderson, B.B. (2006), "Framing a theory of social entrepreneurship: building on two schools of practice and thought", in Mosher-Williams, T. (Ed.), Research on Social Entrepreneurship: Understanding and contributing to an emerging field, Association for Research on Nonprofit Organizations and Voluntary Action, Indianapolis, Ind, pp. 39-66.

Grayson, D., McLaren, M. and Spitzeck, H. (2011), "Social Intrapreneurs - An Extra Force for Sustainability", A Doughty Centre for Corporate Responsibility Occasional Paper, School of Management, Cranfield University, Bedford.

Googins, B.K., Mirvis, P.H. and Rochlin. S.A. (2007), Beyond "good company": next generation corporate citizenship, Palgrave Macmillan, New York, NY.

Hazelton, L.M. and Murray Gillin, L. (2011), "From compliance culture in elder care to resident focus innovation as social entrepreneurship: a global opportunity", in Campbell, C. (Ed.), Proceedings of the 15th Biennial World Marketing Congress: The customer is NOT always right? Marketing operations in a dynamic business world, Reims, France, 2011, pp. 2-11.

Hemingway, C.A. (2004), "Personal values as a catalyst for corporate social entrepreneurship", 17th Annual European Business Ethics Network Conference, University of Twente, Encshede, The Netherlands, 2004.

Hemingway, C.A. (2005), "Personal values as a catalyst for corporate social entrepreneurship", Journal of Business Ethics, Vol. 60, pp. 233-249.

Hemingway, C.A. (2013), Corporate social entrepreneurship: integrity within, Cambridge University Press, Cambridge.

Idowu, S.O., Capaldi, N., Zu, L. and Das Gupta, A. (Eds.) (2013), Encyclopaedia of corporate social responsibility, Springer-Verlag, Heidelberg.

Inglehart, R. (2000), "Globalisation post-modern values", The Washington Quarterly, Vol. 23, No. 1, pp. 215-228.

Ip, M. (2013), "Social intrapreneurship - an idea whose time has come?", Social Entreprise Buzz, 8 January, available at: www.socialenterprisebuzz.com/2013/01/08/social-intrapreneurship-anidea-whose-time-has-come/ (accessed 5 April 2014).

Jones, D. and Keogh, W. (2006), "Social enterprise: a case of terminological amibiguity and complexity", Social Enterprise Journal, Vol. 2, No. 1, pp. 1126. 
Kerlin, J.A. (2010), "A comparative analysis of the global emergence of social enterprise", Voluntas, Vol. 21, pp. 162-179.

Laratta, R., Nakagawa, S., Sakurai, M. (2011), "Japanese social enterprises: major contemporary issues and key challenges", Social Enterprise Journal, Vol. 7, No. 1, pp. 50-68.

Larsen, E.A. (2013), "Taking "Doing well by doing good" to the next level: introducing CSEs as brand extensions", master thesis, Copenhagen Business School, Copenhagen.

Lehner, O.M. and Kansikas, J. (2011), "Social entrepreneurship research across disciplines: paradigmatic and methodological considerations", $3^{\text {rd }}$ EMES International Research Conference on Social Enterprise, Roskilde University, Denmark, 2011.

Liles, D.H., Johnson, M.E., Meade, L.M. and Underdown, D.R. (1995), “Enterprise engineering: A discipline?", Society for Enterprise Engineering Conference Proceedings, 1995.

Mair, J. and Marti, I. (2006), "Social entrepreneurship research: A source of explanation, prediction, and delight", Journal of World Business, Vol. 41, No. 1, pp. 36-44.

Nicholls, A. (2010), "The legitimacy of social entrepreneurship: reflexive isomorphism in a pre-paradigmatic field", Entrepreneurship Theory and Practice, Vol. 34 No. 4, pp. 611-633.

Ostrander S.A. (2007), "The growth of donor control: revisiting the social relations of philanthropy", Nonprofit and Voluntary Sector Quarterly, Vol. 36, No. 2, pp. 356-372.

Park, C. and Wilding, M. (2013), "Social enterprise policy designs: Constructing social enterprise in the UK and Korea", International Journal of Social Welfare, Vol. 22, No. 3, pp. 236-247.

Perez de Mendiguren Castresana, J.C. (2013), "Social enterprise in the development agenda. Opening a new road map or just a new vehicle to travel the same route?", Social Enterprise Journal, Vol. 9, No. 3, pp. 247 268.

Popovici, V. and Muhcina, S. (2012), "Corporate social entrepreneurship as an incubator for tomorrow's leaders", Ovidius University Annals, Economic Sciences Series, Vol. 12, No. 1, pp. 1106-1114.

Prahalad, C.K. (2006), Fortune at the bottom of the pyramid: Eradicating poverty through profits, Prentice Hall, Upper Saddle River, New Jersey.

Ridley-Duff, R.J. and Southcombe, C. (2011), "The social enterprise mark: a critical review of its conceptual dimensions", Social Enterprise Journal, Vol. 8, No. 3, pp. $178-200$.

Simms, J. (2008), "Innovation's new frontier", Director, October, available at: www.director.co.uk/magazine/2008/10\%200ctober/social_intrapreneurs _62_3.html (accessed 23 March 2014).

Schwab, K., (2008), “Global corporate citizenship: working with governments and society", Foreign Affairs, Vol. 87, No. 1, pp 107-118.

SustainAbility (2008), "The social intrapreneur: A field guide for corporate changemakers", SustainAbility, US, available at: www.echoinggreen.org/ sites/default/files/The__Social_Intrapreneurs.pdf (accessed 12 March 2014). 
Tasavori, M. (2012), "Corporate social entrepreneurship at the bottom of the economic pyramid: antecedents and outcomes in India", Doctoral thesis, The University of Manchester, UK.

Teasdale, S. (2010), "What's in a name? The construction of social enterprise", Public Administration Committee (PAC) Conference, Nottingham Trent University, UK, 2010.

TechChange (2014), TC108: Social Intrapreneurship - Innovation Within Institutions, available at: techchange.org/online-courses/socialintrapreneurship-entrepreneurial-strategies-social-innovation-withininstitutions/ (accessed 25 March 2014).

Townsend, J.C. (2012), "How intrapreneurs are building better business from the inside", Co.Exist, 10 December 10, available at: www.fastcoexist.com/1680995/how-intrapreneurs-are-building-betterbusinesses-from-the-inside (accessed 21 April 2014).

Visser, W., Matten, D., Pohl, M., Tolhurst, N., Böhmer, K., Ghebremariam, A., Hennigfeld, J. and Huble, S.S. (2007), The A to $Z$ of corporate social responsibility: a complete reference guide to concepts, codes and organisations, John Wiley \& Sons, Chichester, England.

Wood, D. (2007), "Corporate Social Entrepreneurship," In Visser, W., Matten, D., Pohl, M., Tolhurst, N., Böhmer, K., Ghebremariam, A., Hennigfeld, J. and Huble, S.S. (Eds.) (2007), The $A$ to $Z$ of corporate social responsibility: a complete reference guide to concepts, codes and organisations, John Wiley \& Sons, Chichester, England.

Zadek, S. (2001), The civil corporation: the new economy of corporate citizenship, Earthscan, London, UK.

\section{Appendix 1}

Table 3. Evolution of activities undertaken within corporate social entrepreneurship and social intrapreneurship on Google Scholar

\begin{tabular}{|l|l|l|l|l|l|l|l|l|l|l|l|l|l|}
\hline & $\begin{array}{l}201 \\
5\end{array}$ & $\begin{array}{l}201 \\
4\end{array}$ & $\begin{array}{l}201 \\
3\end{array}$ & $\begin{array}{l}201 \\
2\end{array}$ & $\begin{array}{l}201 \\
1\end{array}$ & $\begin{array}{l}201 \\
0\end{array}$ & $\begin{array}{l}200 \\
9\end{array}$ & $\begin{array}{l}200 \\
8\end{array}$ & $\begin{array}{l}200 \\
7\end{array}$ & $\begin{array}{l}200 \\
6\end{array}$ & $\begin{array}{l}200 \\
5\end{array}$ & $\begin{array}{l}200 \\
4\end{array}$ & $\begin{array}{l}200 \\
3\end{array}$ \\
\hline $\begin{array}{l}\mathrm{CS} \\
\mathrm{E}\end{array}$ & 39 & 105 & 149 & 68 & 67 & 59 & 40 & 35 & 14 & 19 & 4 & 1 & 1 \\
\hline $\mathrm{SI}$ & 42 & 61 & 66 & 57 & 32 & 21 & 12 & 2 & 2 & 2 & 5 & 2 & 1 \\
\hline
\end{tabular}

Source: Authors' own research.

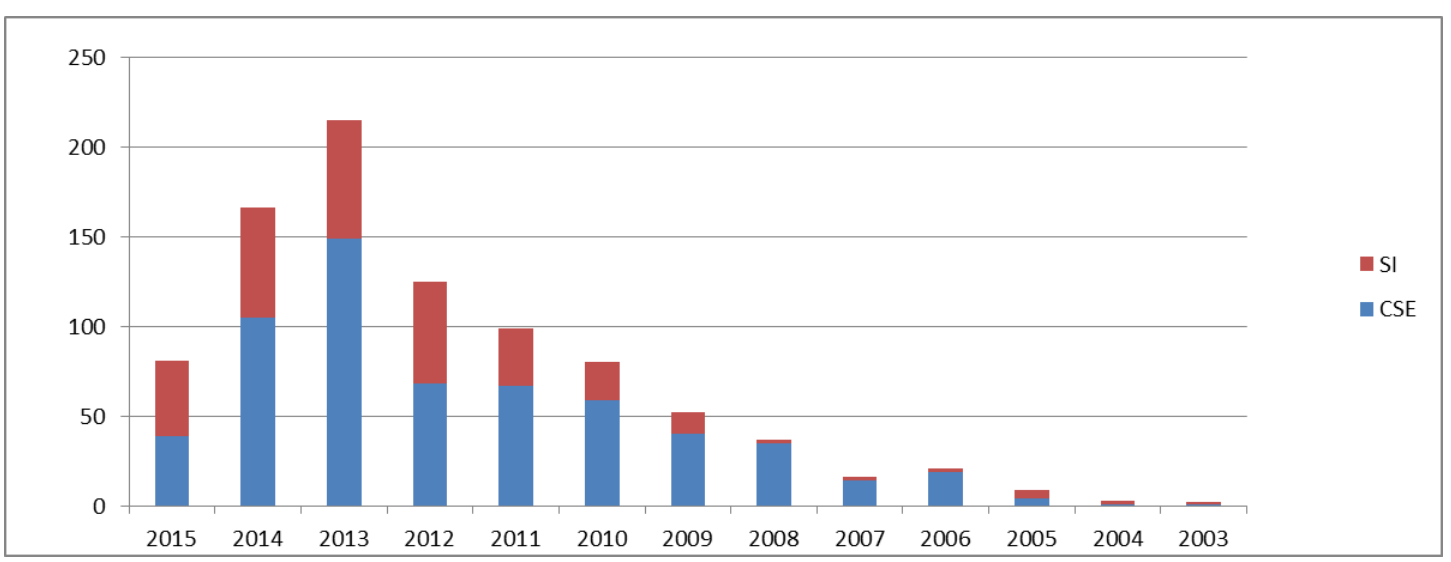


Figure 5. Evolution of activities undertaken within corporate social entrepreneurship and social intrapreneurship on Google Scholar

Source: Authors' own research.

\section{Appendix 2}

Table 4. Statistic on CSE and SI in terms of published articles

\begin{tabular}{|c|c|c|c|}
\hline \multicolumn{4}{|c|}{ Thomson Reuters Web of Science } \\
\hline \multicolumn{2}{|c|}{ CSE in title 5} & \multirow{2}{*}{$\begin{array}{l}\text { Publication } \\
\text { Year } \\
2015\end{array}$} & \multirow{2}{*}{$\begin{array}{l}\text { Citations } \\
0\end{array}$} \\
\hline 1 & $\begin{array}{l}\text { A Corporate } \\
\text { Approach to } \\
\text { Reduction }\end{array}$ & & \\
\hline 2 & $\begin{array}{l}\text { Internationalisation of service firms through } \\
\text { corporate social entrepreneurship and } \\
\text { networking }\end{array}$ & 2013 & 0 \\
\hline 3 & $\begin{array}{l}\text { Corporate social entrepreneurship in every } \\
\text { step of the chain }\end{array}$ & 2013 & 0 \\
\hline 4 & $\begin{array}{l}\text { Corporate Social Entrepreneurship: Integrity } \\
\text { Within }\end{array}$ & 2009 & 1 \\
\hline 4 & $\begin{array}{l}\text { Corporate Social Entrepreneurship Integrity } \\
\text { Within Foreword }\end{array}$ & 2013 & 0 \\
\hline 4 & $\begin{array}{l}\text { Corporate Social Entrepreneurship Integrity } \\
\text { Within Preface }\end{array}$ & 2013 & 0 \\
\hline 5 & $\begin{array}{l}\text { Personal values as a catalyst for corporate } \\
\text { social entrepreneurship }\end{array}$ & 2005 & 69 \\
\hline \multicolumn{4}{|c|}{ Corporate Social Entrepreneur in title 1} \\
\hline 1 & $\begin{array}{l}\text { Corporate Social Entrepreneurship Integrity } \\
\text { Within }\end{array}$ & 2013 & 0 \\
\hline \multicolumn{4}{|c|}{ Social Intrapreneur in topic 6} \\
\hline 1 & $\begin{array}{l}\text { Social Workers as Social Change Agents: } \\
\text { Social Innovation, Social Intrapreneurship, } \\
\text { and Social Entrepreneurship }\end{array}$ & 2015 & 0 \\
\hline 2 & $\begin{array}{l}\text { Innovation for Inclusive Business: } \\
\text { Intrapreneurial Bricolage in Multinational } \\
\text { Corporations }\end{array}$ & 2012 & 18 \\
\hline 3 & $\begin{array}{l}\text { Features of enabling environment that } \\
\text { promotes social intrapreneurism }\end{array}$ & 2012 & 0 \\
\hline 4 & Education for entrepreneurship in nursing & 2011 & 4 \\
\hline 5 & $\begin{array}{l}\text { A process model of social intrapreneurship } \\
\text { within a for-profit company: first community } \\
\text { bank }\end{array}$ & 2011 & 0 \\
\hline 6 & $\begin{array}{l}\text { The Interplay of Form, Structure, and } \\
\text { Embeddedness in Social Intrapreneurship }\end{array}$ & 2010 & 22 \\
\hline \multicolumn{4}{|c|}{ SCOPUS } \\
\hline \multicolumn{2}{|c|}{ Corporate Social Entrepreneurship in title 7} & Year & Citations \\
\hline 1 & $\begin{array}{l}\text { Network, Social entrepreneurship, } \\
\text { internationalization, base of the pyramid, } \\
\text { corporate social entrepreneurship, service } \\
\text { firms }\end{array}$ & 2014 & 0 \\
\hline
\end{tabular}




\begin{tabular}{|c|c|c|c|}
\hline 2 & $\begin{array}{l}\text { Sustainability as a driver for innovation - } \\
\text { towards a model of corporate social } \\
\text { entrepreneurship at Odebrecht in Brazil }\end{array}$ & 2013 & 0 \\
\hline 3 & $\begin{array}{l}\text { [Corporate social entrepreneurship in every } \\
\text { step of the chain]. [Maatschappelijk } \\
\text { ondernemen in elke stap van de keten.] }\end{array}$ & 2013 & 0 \\
\hline 4 & $\begin{array}{l}\text { Corporate entrepreneurship with a purpose: } \\
\text { Exploring the antecedents to corporate } \\
\text { social entrepreneurship }\end{array}$ & 2011 & 0 \\
\hline 5 & $\begin{array}{l}\text { Corporate social entrepreneurship: Integrity } \\
\text { within }\end{array}$ & 2010 & 0 \\
\hline 6 & $\begin{array}{l}\text { Personal values as a catalyst for corporate } \\
\text { social entrepreneurship }\end{array}$ & 2005 & 89 \\
\hline \multicolumn{4}{|c|}{ Corporate Social Entrepreneurship in abstract 3} \\
\hline 1 & $\begin{array}{l}\text { Network, Social entrepreneurship, } \\
\text { internationalization, base of the pyramid, } \\
\text { corporate social entrepreneurship, service } \\
\text { firms }\end{array}$ & 2014 & 0 \\
\hline 2 & $\begin{array}{l}\text { Improving the sustainability and } \\
\text { effectiveness of the inventory management } \\
\text { in manufacturing company }\end{array}$ & 2014 & 0 \\
\hline 3 & $\begin{array}{l}\text { Sustainability as a driver for innovation - } \\
\text { towards a model of corporate social } \\
\text { entrepreneurship at Odebrecht in Brazil }\end{array}$ & 2013 & 0 \\
\hline \multicolumn{4}{|c|}{ Corporate Social Entrepreneurship in keywords 7} \\
\hline 1 & $\begin{array}{l}\text { Network, Social entrepreneurship, } \\
\text { internationalization, base of the pyramid, } \\
\text { corporate social entrepreneurship, service } \\
\text { firms }\end{array}$ & 2014 & 0 \\
\hline 2 & $\begin{array}{l}\text { Improving the sustainability and } \\
\text { effectiveness of the inventory management } \\
\text { in manufacturing company }\end{array}$ & 2014 & 0 \\
\hline 3 & $\begin{array}{l}\text { Sustainability as a driver for innovation - } \\
\text { towards a model of corporate social } \\
\text { entrepreneurship at Odebrecht in Brazil }\end{array}$ & 2013 & 0 \\
\hline 4 & $\begin{array}{l}\text { [Corporate social entrepreneurship in every } \\
\text { step of the chain]. [Maatschappelijk } \\
\text { ondernemen in elke stap van de keten.] }\end{array}$ & 2013 & 0 \\
\hline 5 & $\begin{array}{l}\text { Corporate entrepreneurship with a purpose: } \\
\text { Exploring the antecedents to corporate } \\
\text { social entrepreneurship }\end{array}$ & 2011 & 0 \\
\hline 6 & $\begin{array}{l}\text { Corporate social entrepreneurship: Integrity } \\
\text { within }\end{array}$ & 2010 & 0 \\
\hline 7 & $\begin{array}{l}\text { Personal values as a catalyst for corporate } \\
\text { social entrepreneurship }\end{array}$ & 2005 & 89 \\
\hline \multicolumn{4}{|c|}{ Corporate Social Entrepreneur in all the elements } \\
\hline 1 & $\begin{array}{l}\text { Corporate social entrepreneurship: Integrity } \\
\text { within }\end{array}$ & 2010 & 0 \\
\hline 2 & $\begin{array}{l}\text { Personal values as a catalyst for corporate } \\
\text { social entrepreneurship }\end{array}$ & 2005 & 89 \\
\hline \multicolumn{4}{|c|}{ Social Intrapreneurship in all the elements } \\
\hline 1 & $\begin{array}{l}\text { Social Workers as Social Change Agents: } \\
\text { Social Innovation, Social Intrapreneurship, }\end{array}$ & 2015 & 0 \\
\hline
\end{tabular}




\begin{tabular}{|l|l|l|l|}
\hline & and Social Entrepreneurship & & \\
\hline 2 & $\begin{array}{l}\text { Sustainability as driver for innovation - } \\
\text { towards a model of corporate social } \\
\text { entrepreneurship at Odebrecht in Brazil }\end{array}$ & 2013 & 23 \\
\hline 3 & $\begin{array}{l}\text { Innovation for Inclusive Business: } \\
\text { Intrapreneurial Bricolage in Multinational } \\
\text { Corporations }\end{array}$ & 2012 & 3 \\
\hline 4 & Education for entrepreneurship in nursing \\
\hline 5 & $\begin{array}{l}\text { The interplay of form, structure, and } \\
\text { embeddedness in social intrapreneurship }\end{array}$ & 2012 & 28 \\
\hline Social Intrapreneur in all the elements 1 & $\begin{array}{l}\text { Internal marketing for engaging employees } \\
\text { on the corporate responsibility journey }\end{array}$ & 2012 \\
\hline 1 & \multicolumn{2}{|l|}{ Source: Authors' own research. }
\end{tabular}

